Di:

\title{
NOTES ON DRIED GRASS.
}

R. B. Tennent, Director of the Fields Division, Department of Agriculture, Wellington.

From reports it appears that the dream of agriculturalists is on the eve of realization, and that we are about to enter a new era of agricultural advancement. For long man has realized the fundamental importance of good pasture, and in devious ways has endcavoured to conserve surplus herbage so as to provide. a sufficiency of fodder for his cattle and sheep during lean periods, thereby evolving the technique of haying and silage-making as wC know it to-day.

The process' of haymaking, however, results in a change in the digestibility and nutritive qualities of the grass from which it was made, and the final product in no way resembles the original material. Apart from the actual losses which result in the process of haying, the product has too low a nutritive value in relation to its bulk to form a suitable production diet. Carotene is the chemical precursor of vitamin $A$, its presence greatly, benefiting the health of live-stock and the consumer of animal products, and, although young fresh grass is rich in this respect, the., practice of haymaking destroys practically the whole of these valuable attributes. In short, it would appear that as a result of the development taking place in grass-drying haying will become old-fashioned, wasteful, and uneconomic. This at any rate is the dream apparently about to be realized, and if we consider the claims made for dried grass there would appear to be ample justification for the optimism expressed by investigators.

It will be asked why it is not possible to sun-dry young grass instead of artificially drying it, and so save the cost of expensive machinery, fuel, and so forth. It has to be pointed out that when young grass is sun-dried considerable losses occur. Such losses are due in the first placc to respiration of the freshly cut grass, which continues until the cells die. During this period losses in soluble carbo-hydrates occur, and the loss of dry matter due to this cause may reach as high as Io per cent. Again, during the curing process handling the crop results in mechanical losses, this being higher with clover herbage, much of the leaf being lost. The leaves are by far the richest part of the plant, and the most digestible. This loss is important, reaching on an average from io per cent. to $\mathrm{I}_{5}$ per cent. of dry matter, and even higher. Fermentation of young hay in the stack invariably causes a loss of about 5 per cent. in dry matter, and whicn all these losses are taken into consideration it will be realized how they reduce the value of hay even when made from good young grass. Since the relative proportion of fibre increases as a result of the above losses, the energy required for digestion increases as compared with the fresh crop, thus accounting for a further loss in value.

When grass is dried artificially none of the losses enumerated above take place : hence the value of dried grass against hay made from grass even at a young stage. Young dried grass made from 
monthly cuts has a starch equivalent of $\mathbf{6 0}$ and a protein equivalent of 12 , whereas the average hay crop has a starch equivalent of 50 and a protein equivalent of 4 to 6 .

\section{Value of Dried Grass.}

Already there is considerable literature on the feeding-value of dried grass, and in the main the evidence shows that the drying process (apart from reducing the moisture content from about 80 per cent. to Io per cent.) in no material way alters the composition or feeding-value of the young grass from which it was made. Fresh young grass from 4 in. to 6 in. long is ideal fodder, its protein content on which its feeding-value depends being higher than that of almost any other food. Its starch-value is surpassed only by maize ; it is rich in mineral salts which are assimilated gradually in a natural way impossible with the substitutes used in the winter, when a slowing-up in the growth of young animals takes place. Properly dried grass preserves, all these valuable properties in a highly digestible form, and herein lies. the reason why all those connected with farming are looking forward to the development of the dried-grass industry.

It appears that Dr. Woodman, of the Cambridge School of Agriculture, was the first to attempt to explore the possibilities of dried grass, for in 1926 he produced a small quantity of compressed cakes made from kiln-dried lawn clippings. Imperial Chemical Industries followed this in 1927 with a large-scale trial, undertaking the systematic cutting of some acres of grassland and so regulating the cutting that the herbage was always taken in its young leafy condition. The product, after drying in steamheated troughs, was compressed into cakes, 40 cubic feet of material weighing $\mathbf{I}$ ton. These compressed cakes retained the green colour of fresh grass, had a pleasant smell,. and, when moistened in water, swelled up considerably and disintegrated. They were readily eaten by sheep, and cattle, and feeding-tests carried out with them showed (I) that the drying process at $100^{\circ} \mathrm{C}$. did not impair the high nutritive properties of the 'fresh grass, and (2) that dried grass could successfully replace oil-cakes in the winter ration. of dairy cows and fattening cattle. Where store cattle were receiving $5 \mathrm{lb}$. to $7 \mathrm{lb}$. of dried grass in their rations instead of the usual concentrate mixture, a steady gain of $\mathbf{2} \mathrm{lb}$. per day was averaged during the first two months of fattening and about $I_{\frac{3}{4}} \mathrm{lb}$. per day for the last month. Equally good results were obtained by Woodman and his colleagues at the University Farm with dairy cows fed with dried grass, when the whole of the normal cake allowance and minerals was replaced at the rate of $3 \frac{1}{2} \mathrm{lb}$. per gallon by a mixture of three parts of dried-grass cake and one part of crushed oats, the latter being included to balance the digestible protein in the grass-cake.

The work carried out by 'these investigators naturally led to other workers and other countries studying the possibilities of dried grass, with the result that a multiplicity of drying-machines were manufactured, of varying design, capacities, and efficiency, and feeding-experiments were, put in hand to obtain accurate data on the value of this new dried product. 
It appears reasonable to expect that the application of high temperatures to young grass would detract from its digestibility and feeding-value.

Naturally this question is all-important in assessing the possibilities of dried grass. Woodman showed that grass may be dried at "the temperature of steam " or by direct heat in a kiln, and still retain a high degree of digestibility, comparable to that of fresh grass. Recent research at Jealott's Hill confirmed Woodman's findings. Watson and Ferguson in two series of trials carried out to compare the digestibility of fresh grass with the material obtained by drying grass from the same source and cut at the same time in a band drier at an inlet temperature of $200^{\circ} \mathrm{C}$. found that this process did not affect digestibility of the various constituents, with the possible exception of crude protein. It was further demonstrated that the temperature could be as high as $700^{\circ} \mathrm{C}$., when rapid-drying conditions would result with large output without the material being seriously impaired, provided when dried the grass was immediately removed from contact with the hot gases.

At the Wye Agricultural College in I933 grass was cut when most of the flowering heads had emerged and dried in steamheated hop-kilns. The dried material had a crude-protein content of 13.66 per cent. with $\mathrm{II} \cdot 6$ per cent. digestible protein and a moisture content of 5.2 per cent. An eight-weeks feeding-trial carried out on eighteen ewes showed a gain of $75 \mathrm{lb}$. in the nine animals receiving $\mathrm{I} \mathrm{lb}$. dried grass per head per day in the ration against $64 \mathrm{lb}$. in those receiving equivalent concentrates (oats and cotton-seed meal). In I934 similar experiments were carried out, but the grass was cut earlier, and when dried showed a crude protein content of $\mathrm{I}_{4} \cdot 6$ per cent. The feeding-trial was carried out. on twenty-eight ewes for seven weeks, and the animals on dried grass showed a gain of $40 \mathrm{lb}$. against $24 \mathrm{lb}$. for those on concentrates.

At Jealott's Hill the influence on the colour of butter of dried grass when included in the winter ration of the milking-cow has been investigated. It has been demonstrated that carotene is mainly responsible for the yellow colour of butter, and that there is a close correlation between carotene and vitamen A ; consequently if butter' is low in carotene it will be low in vitamen A. The inclusion of grass silage in the winter diet of the cows did not improve the colour. Dried grass, however, definitely did improve the colour, and where the grass had previously been topdressed with nitrogen the colour was kept at a high level throughout the winter. The trials showed that the inclusion of a sufficient proportion of dried grass in the winter ration resulted in producing butter which in regard to colour and vitamin A was equal to that produced in summer from grass-fed cows.

The possibilities of dried grass are of considerable moment to New Zealand farmers in connection with pig-feeding. Dried grass is in itself a concentrate, and if it can replace or reduce the usual concentrates being fed to pigs it must have a future. Unfortunately, although young- grass has been shown to constituts for ruminants an excellent source of starch equivalent and digestible protein. it by no means follows that it is of similar value to pige. 
Indeed the evidence as to the value of young grass for pig-fattening is meagre, vague, and contradictory. Woodman and $\mathrm{N}$ orman showed that Large White sows weighing $195 \mathrm{lb}$. were unable to digest the constituents of even young grass with anything like the same degree of efficiency as they displayed in the digestion of maize and bran. Their trials, however, pointed to the fact that the consumption by a growing pig of from $6 \mathrm{lb}$. to $7 \mathrm{lb}$. of young grass per day would enable a saving of I $\mathrm{lb}$. of meal, and, assuming that a six-months-old pig will not consume, more than I2 lb. to I4 lb. of green food per day, it is clear that such an allowance of grass, even in its young and most highly digestible condition, will not be equivalent to more than about $2 \mathrm{lb}$. of meal. $\mathrm{T} o$ e $\mathrm{n} \mathrm{s} \mathrm{u} \mathrm{re}$ satisfactory live-weight increases from growing pigs pastured on grass it appears that an adequate ration of concentrates must be given, for not only is the grass less digestible than meal but the herhage is bulky food from the standpoint of swine nutrition, and must tend to restrict the weight of food, in terms of dry matter, which the animal can consume in a day. Whether dried grass, with its. considerably reduced bulk, coupled with the fact that it can be finely ground for pig-feeding, will in essence prove to be better than the original herbage for pig-fattening appears to be debatable, and there is ample scope for work in this direction. From a dietetic viewpoint dried grass is admirable for including in the ration of pigs, and ample evidence is obtainable to show that in this respect it is equal to fresh grass.

$$
\text { GRASS-DRIERS . }
$$

So far as grass-driers are concerned, it is not intended here to attempt to deal with a subject which, apart from being in itself highly specialized, is still in a state of development. Numerous types of machines have been described as suitable for drying : some are already on the market, and indications are that as investigations into the possibilities of grass-drying proceed modifications of existing machines will take place, new machines will be designed, and a greater all-round efficiency in drying will be obtained.

It is, however, to be pointed out that at present there are two main classes. of machines, one for the individual farmer's use (usually looked upon as a small-scale plant, although generally fairly costly) and the other a co-operative or factory-type plant of considerable size, high cost, and large daily output. The question as to which class of machine will eventually be adopted by the farming community must necessarily await the fullest economic examination of the capabilities of the various types on the market, but---from- an efficiency viewpoint it would appear that if grassdrying is ever to play a part in the Dominion development will be along the lines of factory driers with a large daily capacity run on co-operative lines. This undoubtedly will mean the evolving of special methods of grassland management, for grass-farming, to supply grass-driers, will have to be put on a specially organized basis. Combined grazing and mowing raises particular problems of farm-management. Special pastures intended for cutting only will necessitate special treatment and seed mixtures so as to stand 
up to repeated mowing. The maintenance of fertility under these conditions will in itself bc a difficult problem, and although the best grasses and clovers may economically justify drving, not all types of pasture will reach or maintain a sufficiently high standard for this purpose. Pastures will have to be managed so that they come to a state ready for cutting in steady succession at the right time and so prevent all maturing together. These and many other problems would inevitably have to be faced and solved if grassdrying was undertaken, not only on co-operative lines but by individual farmers.

The magnitude of production in the Dominion from normally good pastures is not fully appreciated. From 2Ist November, 1935, to 17 th January, 1936, a period of ninety-nine days, the total green material harvested from a field at Marton Experimental Area top-dressed with superphosphate amounted to $\mathrm{r} 2 \cdot 2$ tons with a dry-matter content of over 2 tons per acre. During the same period at Kuakura last season, in III days the total green material produced from a field manured with supcrphosphate and lime amounted to $I I \frac{1}{2}$ tons per acre, with a dry-matter content of in excess of 2 tons. Production figures such as these are by no means abnormal, and amply illustrate the facilities in raw material which are available on the average good farm for the production of dried grass.

No description of the systems of drying at present being adopted has been given, nor has mention been made of the cost and production of driers already on the market. As already indicated, however, these may be as yet regarded as in the experimental stage, and considerable improvements in existing machines may bc looked for.

Broadly speaking, there are four systems of drying-tray driers, as exemplified by the Billingham drier ; conveyor driers, as in the Ransome -Sim-Jefteries belt conveyor machine; pneumatic driers, as in the "Pherson" drier, a continental machine ; and vacuum rotary driers, in which the material is dried under vacuum. All are more or less efficient, but the cost and output of dried material differ materially. For example,. in the case of the Billingham No. 2 drier, the cost of this machine in England with baler is $\$ 75^{\circ}$, to which has to be added the cost of foundations and housing. Erected in the Dominion this machine would cost approximately $f \mathrm{I}, 200$. The makers claim a production capacity for this drier of $33 \mathrm{cwt}$. of dried grass, from 6 to 8 tons of wet grass in 8 hours (a $3 \frac{1}{2}$ to $I$ water ratio) at a cost in England of $\{38 \mathrm{~s}$. per ton of dried material. The Phcrson drier, which is a large factory unit manufactured in Denmark, working partly on the pneumatic and partly on the revolving-drum principle, according to the New Zealand representative, Mr. Jorgensen, of Wellington, would cost erected here f4,000. This machine is reputed by the makers to have an output of I $6 \frac{1}{2}$ cwt. of dried grass per hour at a cost of $f_{\mathrm{I}} 7 \mathrm{~s}$. per ton, A drier of this type is obviously a grass-drying factory in itself, and to operate efficiently it would be essential to have organized supplies of grass and other herbage such as lucerne coming forward to ensure drying operations being conducted over a considerable portion of the year. Such types of plants operating in special districts on co-operative lines would appear to have distinct possibilities. 


\section{Value OF Dried Grass to the Dominion.}

Sufficient has been said to show that the value of dried grass has been established in so far as its digestibility and nutritive qualities are concerned. It has- been shown for practical purposes to be almost as good as the herbage from which it is made. Efficient drying-machines are already on the market, and new and probably more efficient ones are being built. The question then arises as to dried-grass production ever becoming an important feature of herbage-conservation in this country, and before that question can be satisfactorily answered good uses have to be found for dried grass. We cannot afford to ignore this most striking development in agricultural science, and none of us yet knows its latent possibilities. New Zealand, depending primarily on animal products manufactured from grass, has at her hand if she wants it a means of conserving her wealth of surplus grass in a form which in no way materially detracts from its value. The production of out-ofseason grass has been one of our aims, and perhaps it will only be realized by having on hand an adequate store of dried material.

Steps already have been taken by the Department of Agriculture. through the courtesy of th N.Z. Co-operative Dairy Co., to have a large supply of grass dried at its Frankton factory, and arrangements are in train to import a drying plant which in all probability will be placed at the Ruakura Training Farm, so that ample opportunities will be afforded to test out the value of dried grass. There is no question about it, we have to get right into this dried-grass business and find out if it is worth fitting into our farming. There are many points upon which we require definite information and that information can be obtained only by conducting trials in this country under our own climatic and soil conditions, with our own pastures and stock.

To the pig-feeder it is all-important to know what dried grass has in store for him. Is it a cheap concentrate and will it replace skim-milk or replace meat-meal ? Can our large and ever-increasing bill for imported Australian-grown barley be reduced by the usc of Dominiongrown dried grass ?

To the dairy-farmer with early calves and no young grass, dried grass would appear to be invaluable, and, when bloat begins to cause trouble and losses, might it-not be advisable, instead of grazing the animals on "bloat " pastures, to cut such pastures for dried grass, or, if facilities do not offer, for young-grass silage, feeding bought-in dried grass to the stock in the meantime. Points at least worth looking into.

To the town milk-supplier dried grass would appear to be invaluable, retaining milk-supply, colour, quality, vitamin content, and freedom from taint.

Investigations are necessary to find out -the effect of dried grass in preventing feed-flavours in milk in such districts as the Waikato, where one can foresee the possibility of badly tainting pastures being utilized for the production of dried grass, the animals being fed on at least a portion of the dried material which presumably would be non-tainting.

Sheep take freely to dried grass, and hogget troubles might well be overcome by feeding dried material.

There may be very little in the possibilities suggested; but, until we look into the whole question from the viewpoint of the dairy-farmer, pig-feeder, cattle-raiser, sheep-farmer, and poultry-keeper, we will have 
to retain an open mind on the subject of grass-drying, and before summarily, dismissing it as uneconomic under our conditions we must satisfy ourselves by actual trial of the material as to whether it is, as it would appear to bc, a most valuable form of conserved stock-food which should be used extensively by our farmers.

\section{Discussion.}

Mr. Palmer: What is the cost of production of dried grass ?

Mr. Tennent: In the Billingham drier, the small one, the English cost is computed at $f_{3} 8 \mathrm{~s}$. a ton. In the big drier the costs is $f_{1} \mathrm{I} 5 \mathrm{~s}$. a ton. We have no information about costs here, because we have never had dried grass. No matter what the cost is in the case of any machine we bring out, if we find that the material is good we may expect eventually to get efficient machines that will operate at a cost that is economic.

Mr.' Hudson : Mr. Levy quoted figures which showed that at Marton on good pastures, but on country not considered first-class, the average annual production of dry matter for three years has been 5 tons per acre. Let us assume $\mathbf{2}$ tons per acre is produced in the high-production period. That is worth Against that you have the cost, f I I.5s. per ton. Unfortunately, the enormous drain on the fertility of our land must be taken into account if we consider exporting such'a commodity. It looks as if there may be possibilities of building up something of an export trade.

Mr. Cockayne : Any method of drying grass must be of very particular moment to New Zealand.. At this stage one is not concerned with the costs or the mcthods or types of machines or whether the material is produced by the farmer by himself or produced in co-operation. The utilization of dried grass is the basic matter about which we should get information. Overseas experiments do not cover the really essential matters we want to know about. The European experiments as a whole, up to the present, have only viewed the use of dried grass as a means of replacing a certain percentage of the bought-in ration that the stock farmer may be using for his stock. so far as pigs are concerned, only a small portion of the total daily ration was in the form of dried grass in these experiments. We want to find out whether dried grass can completely replace in the feeding of our stock at any period of the ycar an equivalent adequate ration of young grass. If dried grass can perform that function, the question of types of apparatus, of cost, of how and where grass for the purpose of drying will be produced, are matters that will automatically become solved. If it can replace the ration then with our ability to produce grass a complete revolution in the whole of our livestock feeding in New Zealand can come about. It was for that reason that, when I took over my present position, I decided we must get experiments going on those lines. The New Zealand Dairy Co. have placed at the disposal of the Fields Division their large casein-drier at 'Hamilton on certain days of the week. 